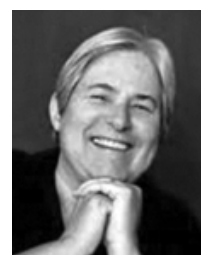

Nancy E. Snow •

\title{
ETYKA CNÓT KONTRATAKUJE. ODPOWIEDŹ NA ZARZUTY SYTUACJONISTÓW
}

Stowa kluczowe etyka cnót, sytuacjonizm, arystotelizm, charakter

\section{Streszczenie}

Czy w świetle krytyki sytuacjonistów pod adresem etyki cnót można powiedzieć, że istnieje coś takiego jak cnota czy charakter? Uważam, że tak - w tradycyjnym filozoficznym znaczeniu tych terminów, bronionym przez Arystotelesa. Moje uzasadnienie tego twierdzenia składa się z kilku kroków. W części pierwszej przedstawiam swoje rozumienie standardowej Arystotelesowskiej koncepcji cnót i ich związku z działaniem; koncepcja ta stanowi cel sytuacjonistycznej krytyki etyki cnót. W części drugiej przedstawiam zarzuty wysuwane przez sytuacjonistów pod adresem cech globalnych, zaś w części trzeciej proponuję możliwą linię obrony. Te dwie części opierają się w znacznej mierze na mojej książce Virtue as Social Intelligence: An Empirically Grounded Theory. W częściach czwartej i piątej odpieram niedawne ataki sytuacjonistów na koncepcję poznawczej spójności osobowości i analizuję kilka strategii obrony, które można znaleźć w filozoficznej i psychologicznej literaturze dotyczącej cnót.

Spis treści

I. Tradycyjna koncepcja Arystotelesowska

2. Sytuacjonistyczna krytyka cech globalnych

3. Filozofia i psychologia kontratakują

4. Sytuacjonistyczna krytyka jedności poznania

5. W kierunku bardziej ujednoliconego ujęcia procesów poznawczych

6. Wniosek 
łówne pytanie tej monografii brzmi następująco: czy w świetle krytyki sytuacjonistycznej można przyjąć, że istnieje charakter bądź cnota? Uważam, że tak - w tradycyjnym filozoficznym sensie terminów „cnota” i „charakter”, bronionym przez Arystotelesa. Moje uzasadnienie tego twierdzenia składać się będzie $z$ kilku kroków. W części pierwszej przedstawię swoje rozumienie standardowej Arystotelesowskiej koncepcji cnót i ich związku z postępowaniem. Koncepcję tę (i jej podobne) przyjmuje - w szerokim zarysie - większość współczesnych etyków cnoty, nawet tych niezwiązanych z Arystotelesem'. Stanowi ona cel sytuacjonistycznej krytyki etyki cnoty. W części drugiej przedstawiam zarzuty wysuwane przez sytuacjonistów pod adresem cech globalnych, zaś w części trzeciej proponuję możliwą linię obrony. Te dwie części opierają się w znacznej mierze na mojej książce Virtue as Social Intelligence: An Empirically Grounded Theory. W częściach czwartej i piątej odpieram niedawne ataki sytuacjonistów na koncepcję poznawczej spójności osobowości. Opieram się w nich na swoim artykule Situationism and Character: New Directions, który ukazał się w książce Handbook of Virtue Ethics pod redakcją Stana van Hoofta (London \& New York: Routlege, 2014).

\section{Tradycyjna koncepcja Arystotelesowska}

Zgodnie z ujęciem Arystotelesa cnota to stały stan charakteru przejawiający się w cnotliwym postępowaniu w wielu różnych sytuacjach. I tak na przykład jeśli posiadam cnotę uczciwości, można oczekiwać, że będę uczciwa, zeznając pod przysięgą w sądzie,

Zob. L.T. Zagzebski, Virtues of the Mind: An Inquiry into the Nature of Virtue and the Ethical Foundations of Knowledge, New York 1996; R. Hursthouse, On Virtue Ethics, Oxford 1999; C. Swanton, Virtue Ethics. A Pluralistic View, Oxford 2003; D.C. Russell, Practical Intelligence and the Virtues, Oxford 2009; N. Snow, Virtue as Social Intelligence: An Empirically Grounded Theory, New York 20Io; J. Annas, Intelligent Virtue, New York 20II. 
odprowadzając podatek dochodowy czy w relacjach z małżonkiem. Zgodnie z tradycją etyki cnót uważa się je za trwałe i złożone ontologicznie dyspozycje ludzkiej osobowości. Integralną ich częścią są przekonania, pragnienia i afekty. Cnoty nie są bezwładne, lecz mogą wywoływać działanie. Mają one również inne role, jak na przykład kształtowanie poglądów i sądów, lecz w tym artykule skupię się na ich związku z działaniem.

Cnoty są związane $z$ działaniem na kilka interesujących sposobów. Po pierwsze, nawykowe działania prowadzą do nabywania cnotliwych dyspozycji. Niestety, Arystoteles nie poświęca temu zagadnieniu tak dużo uwagi, jakbyśmy chcieli. Niemniej, jak przypomina Julia Annas², działania, o których pisze Arystoteles, nie są podejmowane bezmyślnie, lecz kierują nimi rozum oraz cnotliwi nauczyciele. Tych, którzy uczą się, jak być cnotliwymi ludźmi, trzeba tak prowadzić, by rozumnie wybierali sposób postępowania i czerpali z tego przyjemność. Przyjemność jest tu rzeczą kluczową, gdyż stanowi pierwszą motywację do dokonywania właściwych wyborów. Koncepcja Arystotelesa przedstawia się więc następująco: działania, które - podejmowane pod wpływem rozumu oraz pod przewodnictwem cnotliwego nauczycielaweszły w nawyk i sprawiają przyjemność, są pierwszym krokiem na drodze nabywania cnotliwych dyspozycji. W miarę rozwoju człowiek cnotliwy będzie - w sytuacji idealnej - wybierać cnotliwe działania $z$ uwagi na nie same, a nie jedynie przyjemność, którą przynoszą.

Cnotliwe dyspozycje wpływają na działania na dwa sposoby, które - na pierwszy rzut oka - wzajemnie się wykluczają. Pierwszy $z$ nich to przemyślany i odpowiednio umotywowany wybór. Drugi wiąże się $z$ mniej jasnym pojęciem „drugiej natury"3. Wywoływanie cnotliwych działań poprzez wybór rozumiem jako formę kierowania się racjami ${ }^{4}$. Cnotliwy człowiek posiada

2 J. Annas, Intelligent Virtue, dz. cyt.

3 J. McDowell, Two Sorts of Naturalism [w:] R. Hursthouse, G. Lawrence, W. Quinn (eds.), Virtues and Reasons: Philippa Foot and Moral Theory, Oxford I995.

4 Zob. D.C. Russell, Practical Intelligence..., dz. cyt., rozdz. II; J. McDowell, Virtue and Reason, „Monist” 62 (I979), s. 33I-350. 
dyspozycję, dzięki której postrzega fakty w taki sposób, że dostarczają mu one racji do cnotliwego działania. Na przykład widok osoby zanoszącej się płaczem dostarcza człowiekowi litościwemu racji do zaoferowania jej pomocy. Przy takim postrzeganiu tej sytuacji korzysta on z rozsądku - bez którego, zdaniem Arystotelesa, człowiek nie może być cnotliwy - by zdecydować, (a) że pomoże i (b) jak pomoże. Zdolność do właściwego namysłu (składnik rozsądku) pozwala mu właściwie utrafić w przedmiot cnoty ${ }^{5}$.

Nieodłączną częścią cnoty jest właściwa motywacja. Człowiek cnotliwy pomaga, bo ktoś inny jest w potrzebie lub dlatego, że tak należy. Cnota ukierunkowuje swojego posiadacza na dobro i skłania go do podejmowania cnotliwego działania we właściwy sposób, tj. taki, w którym ta cnota prawdziwie się wyraża. Odpowiednich rodzajów motywacji może być nieskończenie wiele, ponieważ cnoty rozwijają się z biegiem ludzkiego życia. Znaczy to, że kształt cnoty zależy od przebiegu życia każdego konkretnego człowieka i roli, jaką odgrywa ona na tle innych cech jego osobowości. W zależności od przebytych doświadczeń, jedna osoba może stwierdzić, że dana sytuacja wymaga sprawiedliwości, podczas gdy inna dostrzeże w niej rację łaski albo rozejmu. Tak więc cnoty pozwalają ustosunkować się do faktów poprzez dostarczanie racji do działania, i to w sposób zależny od tego, jak te cnoty kształtowały się u poszczególnych ludzi.

A co z rozumieniem cnotliwych działań w myśl teorii „drugiej natury"? Pojęcie to jest niejasne, gdyż Arystoteles pozostawił wiele niedopowiedzeń. W myśl tego rozumienia stosunku cnotliwych dyspozycji do działań człowiek cnotliwy nie musi - jak się zdaje - świadomie się namyślać, lecz po prostu działa, jakby powodowany „drugą naturą”. Znaczy to, że człowiek cnotliwy nabrał takiego przyzwyczajenia do cnotliwego działania, że nie musi zastanawiać się, czy i jak je podjąć - działanie takie po prostu wypływa $z$ jego charakteru. Na pierwszy rzut oka koncepcja „drugiej natury” zdaje się wykluczać z koncepcją, w myśl której

D.C. Russell, Practical Intelligence..., dz. cyt., s. 24. 
cnotliwe działanie wymaga przemyślanego wyboru, jednak ja nie widzę tu żadnego faktycznego napięcia. Czy cnota rozumiana jako swego rodzaju „druga natura” jest również formą kierowania się racjami? Uważam, że tak, i postaram się poprzeć to odpowiednimi argumentami.

\section{Sytuacjonistyczna krytyka cech globalnych}

Nakreślona wyżej koncepcja jest - przynajmniej w pewnych aspektach - celem sytuacjonistycznej krytyki etyki cnoty. Przebiega na dwóch frontach. Na pierwszym $z$ nich atakuje się pojęcie globalnych lub mocnych cech, tj. cech, które trwale przejawiają się w zachowaniu w różnych sytuacjach. Do takich cech prawdopodobnie zaliczają się cnoty. Sytuacjoniści argumentują, że nie ma wielu lub zgoła wcale empirycznych dowodów psychologicznych na szeroki udział cech globalnych w wywoływaniu zachowania. Druga, młodsza linia krytyki głosi, że ujednolicone i w znacznym stopniu refleksyjne pojęcie poznania, na którym opiera się etyka cnoty, nie znajduje poparcia w empirycznej psychologii. Ogólnie, obie te linie ataku utrzymują, że etyce cnoty brak empirycznego oparcia pod dwoma kluczowymi względami: ani pojęcie cechy, na której etyka cnoty się opiera, ani pojęcie refleksyjnej racjonalności nie znajdują poparcia w empirycznej psychologii. Wynikiem tej dwutorowej krytyki jest twierdzenie, że osobowość i procesy poznawcze są zbyt pofragmentowane, by poprzeć ujednoliconą koncepcję charakteru, zakładaną przez etyków cnoty. Oba te zarzuty były formułowane przez czterech filozofów: Gilberta Harmana, Johna M. Dorisa, Stephena P. Sticha i Marię W. Merritt ${ }^{6}$.

6 Krytyka cech: G. Harman, Moral Philosophy Meets Social Psychology: Virtue Ethics and the Fundamental Attribution Error, „Proceedings of the Aristotelian Society”, New Series 99 (1999), s. 315-33I; tenże, The Nonexistence of Character Traits, „Proceedings of the Aristotelian Society” 100 (2000), s. 223-226; J.M. Doris, Persons, Situations, and Virtue Ethics, "Nous” 32 (I998), s. 504-530; 
Najbardziej radykalnym krytykiem etyki cnoty jest Harman? ${ }^{7}$ Twierdzi, że empiryczna psychologia nie dostarcza nam żadnych racji, by sądzić, że istnieją cechy globalne, a co za tym idzie - że jest coś takiego jak charakter w tradycyjnym filozoficznym rozumieniu. Przyznaje on wprawdzie, że pewne koncepcje cnoty, jak na przykład ta głoszona przez Judith Jarvis-Thomson i Julię Driver, nie opierają się na pojęciu cech ogólnych i tym samym unikają sytuacjonistycznej krytyki, niemniej twierdzi, że rozprawianie o cnocie jest szkodliwe i powinno się go zaniechać. Bardziej umiarkowanym - na pierwszy rzut oka - krytykiem jest Doris ${ }^{8}$. Przyznaje on 9 , że wyniki współczesnych eksperymentów z zakresu psychologii społecznej dają się pogodzić z tym, że niewielka liczba ludzi posiada cechy globalne, niemniej twierdzi, że - jak wynika $z$ większości świadectw - cechy te nie odgrywają wielkiej roli w wywoływaniu zachowania. Jego zdaniem psychologia społeczna dowodzi, że cechy mają charakter lokalny lub są wąsko przypisane obiektywnym właściwościom danej sytuacji ${ }^{10}$. Możemy mówić o towarzyskości na imprezie firmowej lub uczciwości przy odprowadzaniu podatków, ale nie o towarzyskości czy uczciwości tout court. Mówiąc ogólnie, Doris uważal1, że osobowość jest zbyt pofragmentowana, by można było przyjmować globali-

tenże, Lack of Character: Personality and Moral Behavior, Cambridge 2002; tenże, Précis of Lack of Character, „Philosophy and Phenomenological Research” 7I (2005), s. 632-634; J.M. Doris, S.P. STich, As a Matter of Fact: Empirical Perspectives on Ethics [w: F. Jackson, M. Smith (eds.), The Oxford Handbook of Contemporary Philosophy, New York 2005, s. II4-I52; M.W. Merritt, Virtue Ethics and Situationist Personality Psychology, „Ethical Theory and Moral Practice” 3 (2000), s. 365-383. Krytyka racjonalności: J.M. Doris, Skepticism about Persons, "Philosophical Issues” I9 (2009), s. 57-9I; M.W. Merrit t, Aristotelian Virtue and the Interpersonal Aspect of Ethical Character, "Journal of Moral Philosophy" 6 (2009), s. 2-49; M.W. Merritt, J.M. Doris, G. Harman, Character [w:] J.M. Doris i the Moral Psychology Research Group (eds.), The Moral Psychology Handbook, Oxford 2010, s. 355-40I.

7 G. Harman, Moral Philosophy Meets Social Psychology..., dz. cyt., s. 316; tenże, The Nonexistence of Character Traits..., dz. cyt., s. 223.

Tamże, s. 6 .

Tamże, s. 62.

Tamże, s. 22. 
styczne koncepcje charakteru, które przypisuje on etykom cnoty ${ }^{12}$. Merritt również przyjmuje sytuacjonistyczne interpretacje badań z zakresu psychologii społecznej i proponuje koncepcję cnoty, zgodnie $z$ którą jest ona czymś podtrzymywanym $z$ zewnątrz przez czynniki społeczne ${ }^{13}$. Doris zbliżył się ostatnio do stanowiska Harmana ${ }^{14}$, dotyczącego empirycznej niemożliwości cech oraz charakteru, i twierdzi, iż to na etykach cnót spoczywa ciężar udowodnienia, że tradycyjne filozoficzne koncepcje cnoty i charakteru są empirycznie możliwe ${ }^{15}$.

$\mathrm{Na}$ poparcie swoich tez sytuacjoniści przytaczają cały zbiór badań z zakresu psychologii społecznej, w których to sytuacje, a nie cechy, zdają się być głównym czynnikiem wpływającym na zachowanie. Te czynniki sytuacyjne często są trywialne, jak na przykład znalezienie dziesięciocentówki w budce telefonicznej, lub działają poniżej poziomu świadomości, jak na przykład oświetlenie pokoju czy zapach. Opiszę teraz trzy spośród badań, na które powołują się sytuacjoniści.

\subsection{Badania nad efektem nastroju}

Ulubionym badaniem sytuacjonistów nad wpływem nastroju na zachowanie jest eksperyment Alice Isen i Pauli Levin ${ }^{16}$. Badaczki te odkryły, że jedyną istotną zmienną w sytuacji, w której badani w centrum handlowym przystawali, by pomóc komuś pozbierać

12 „Globalistyczna” koncepcja charakteru spełnia 3 warunki: (I) konsekwencja - powtarzalne przejawianie się cech w zachowaniu, rozciągające się na wiele różnorodnych sytuacji; (2) stałość - powtarzalne przejawianie się cech w podobnych sytuacjach; (3) normatywna spójność - skupianie się cech o podobnej wartości w ramach jednej osobowości. Na przykład osoba posiadająca pozytywne cechy, takie jak szczodrość, będzie zazwyczaj posiadała również inne pozytywne cechy, takie jak uprzejmość czy współczucie. To samo tyczy się również cech negatywnych (J.M. Doris, Lack of Character..., dz. cyt., s. 22).

13 M. Merritt, Virtue Ethics..., dz.cyt.

14 G. Harman, Moral Philosophy Meets Social Psychology..., dz. cyt.

15 J.M. Doris, S.P. STich, As a Matter of Fact..., dz. cyt., s. I2I.

16 A.M. Isen, P.F. Levin, Effect of Feeling Good on Helping: Cookies and Kindness, "Journal of Personality and Social Psychology" 2I (I972), s. 384-388. 
rozrzucone na ich drodze dokumenty, było to, czy przed chwilą znaleźli w automacie telefonicznym dziesięciocentówkę. Spośród I6 badanych, którzy znaleźli monetę, tylko dwóch nie udzieliło pomocy przy dokumentach; spośród 25 uczestników, którzy nie znaleźli monety, pomógł zaledwie jeden. Isen i Levin doszły do wniosku, że pozytywna emocja wywołana w ich badaniu przez czynniki sytuacyjne doprowadziła do zachowania polegającego na udzieleniu pomocy. Sytuacjoniści utrzymują, że gdyby ludzie posiadali cechy globalne, takie jak współczucie, to z pewnością przystanęliby, żeby udzielić pomocy nawet wówczas, gdyby przedtem nie znaleźli dziesięciocentówki. Trywialne czynniki sytuacyjne nie powinny wpływać na realizowanie cnoty.

Badanie Isen i Levin nie zostało powtórzone, ale istnieje mnóstwo innych eksperymentów nad efektem nastroju, w których uzyskuje się podobne wyniki i które - zdaniem sytuacjonistów - dowodzą tej samej tezy. Odkryto na przykład, że wąchanie przyjemnych zapachów w centrum handlowym ${ }^{17}$ lub odpowiednia temperatu$\mathrm{ra}^{18}$ wpływały na pomaganie innym. Szczerze powątpiewam, żeby badania nad efektem nastroju były istotne dla etyki cnoty. Wiele sytuacji badanych w tych eksperymentach wymagało trywialnej pomocy, takiej jak wypełnienie ankiety w centrum handlowym czy rozmienienie jednodolarowego banknotu. Nie jest jasne, które spośród cnót miałyby stać za tego rodzaju działaniami i tym samym ujawnić się (bądź nie) w tych eksperymentach. Co więcej, wyniki badań nad efektem nastroju zgadzają się $z$ tym, że niewielu ludzi posiada pewne cnoty, a przynajmniej pewne formy uprzejmości. Skoro etycy cnoty uważają, że cnotliwi ludzie należą do rzadkości, zaobserwowany brak pomocy pod nieobecność przyjemnego bodźca nie musi przeczyć ich twierdzeniom. Co więcej, cnotliwe motywy mogą działać obok tych wzbudzonych poprzez wywołane określoną sytuacją uczucie, które prowadzi do pomagania innym.

17 R. Baron, The Sweet Smell of... Helping: Effect of Pleasant Ambient Fragrance on Prosocial Behavior in Shopping Malls, „Personality and Social Psychology Bulletin" 23 (I997), s. 498-503.

18 C. Anderson, W. Deuser, K. Deneve, Hot Temperatures, Hostile Affect, Hostile Cognition, and Arousal: Tests of a General Model of Affective Aggressiveness, „Personality and Social Psychology Bulletin” 2I (I995), s. 434-448. 


\subsection{Eksperyment w seminarium duchownym w Princeton}

Kolejne badanie chętnie przytaczane przez sytuacjonistów to eksperyment Johna Darleya i Daniela Batsona ${ }^{19}$. Uczestnikami tego słynnego badania byli seminarzyści z Princeton. Niektórzy spośród nich, spiesząc się na wygłoszenie przemówienia, przechodzili obok leżącego i jęczącego człowieka, najwyraźniej potrzebującego pomocy. Nie wiedzieli, że w rzeczywistości był on pomocnikiem eksperymentatorów. Spośród 40 badanych I6 (40\%) zaoferowało ofierze bezpośrednią lub pośrednią pomoc; 24 (60\%) nie zrobiło tego ${ }^{20}$. W warunkach małego pośpiechu pomoc zaoferowało $63 \%$ badanych, w warunkach umiarkowanego pośpiechu - 45\%, zaś w warunkach dużego pośpiechu - IO\%. Wyniki te zgadzają się $z$ twierdzeniem, że niewielu ludzi okazuje współczucie. Zdarzało się jednak, że obok „ofiary” przechodzili obojętnie ci seminarzyści, którzy mieli omawiać przypowieść o dobrym Samarytaninie ${ }^{21}$. Badacze odkryli, że jedyną istotną zmienną wpływającą na udzielenie pomocy był stopień pośpiechu uczestników eksperymentu.

Sytuacjoniści nie wspominają o kontynuacji tych badań przeprowadzonej przez Batsona i jego współpracowników ${ }^{22}$. Chcieli sprawdzić hipotezę, że istotnym czynnikiem zmniejszającym prawdopodobieństwo pomocy jest problem, komu pomóc, a nie pośpiech sam w sobie. Uczestnikom tego badania - studentom płci męskiej - mówiono, że ich dane będą lub nie będą ważne dla opracowywanego przez ich kolegów projektu, po czym proszono ich o dołączenie do tych kolegów w innym budynku, by ukończyli projekt. Połowie z nich powiedziano, że są spóźnieni i muszą się pospieszyć; drugiej połowie powiedziano, że mają dużo czasu. W drodze do drugiego budynku wszyscy napotykali leżącego na

19 J.M. Darley, C.D. Batson, From Jerusalem to Jericho: A Study of Situational and Dispositional Variables in Helping Behavior, "Journal of Personality and Social Psychology" 27 (I973), s. I00-I08.

20 Tamże, s. 104-105.

21 Tamże, s. I07.

22 C.D. BAtson i in., Failure to Help When in a Hurry: Callousness or Conflict?, „Personality and Social Psychology Bulletin” 4 (I978), s. 97-Ior. 
ziemi i jęczącego mężczyznę. Spośród ro badanych, którym się nie spieszyło i których dane nie były ważne dla projektu, 8 przystawało, by pomóc; w grupie, której się spieszyło i której dane nie były ważne dla projektu, przystawało 7 spośród ıo badanych; w grupie, której się nie spieszyło i której dane były ważne, przystawało 5 spośród Io uczestników; w grupie, której się spieszyło i której dane były ważne, zatrzymał się tylko jeden badany spośród ro. Tak więc badani, na których pomoc nie liczyli ich koledzy, zatrzymywali się bez względu na to, czy im się spieszyło, czy nie. Badacze doszli do wniosku, że pośpiech sam w sobie nie zmniejszał prawdopodobieństwa udzielenia pomocy. Istotnym czynnikiem nie była zatem bezduszność, lecz problem, komu pomóc.

\subsection{Eksperymenty Milgrama nad posłuszeństwem}

W badaniach Stanleya Milgrama, powtarzanych w wielu krajach w różnych wariantach, brali udział przedstawiciele różnych zawodów. Powiedziano im, że eksperyment dotyczy wpływu karania na pamięć. Mieli oni odgrywać rolę "nauczycieli” i aplikować coraz mocniejsze wstrząsy elektryczne (aż do 450 woltów) „uczniom”, którzy w rzeczywistości byli pomocnikami eksperymentatorów. Wstrząsy elektryczne były fałszywe, a eksperyment dotyczył tak naprawdę postaw wobec autorytetów. Pytanie, które postawił Milgram ${ }^{23}$, brzmiało: „W jakich warunkach badany będzie stosował się do polecenia wyrządzenia krzywdy innej osobie, a w jakich odmówi posłuszeństwa?”.

Eksperyment Milgrama zyskał złą sławę z powodu dużej liczby badanych, którzy kontynuowali wymierzanie wstrząsów elektrycznych aż do najwyższego poziomu, wbrew przypuszczeniu psychologów, którzy sądzili, że badani przerwą eksperyment, zanim dojdą do silnych impulsów. Różne warianty eksperymentu wykazały, że posłuszeństwo badanych wobec autorytetu było wysoce zależne od czynników sytuacyjnych. Na przykład w jednej z wersji "nauczyciele” mieli siłą opuszczać rękę "ucznia” na

23 S. Milgram, The Individual in a Social World: Essays and Experiments, Reading, MA 1977, s. I02. 
blaszaną płytkę, żeby zaaplikować wstrząs. W tych warunkach $70 \%$ badanych przeciwstawiło się eksperymentatorowi. W innych wariantach posłuszeństwo było mniejsze, gdy eksperymentator nie był fizycznie obecny w laboratorium. Z kolei gdy dwóch eksperymentatorów wydawało sprzeczne polecenia - jeden nakazywał dalej wymierzać wstrząsy, a drugi przestać - wszyscy badani przerywali ${ }^{24}$. Gdy dwóch badanych odmawiało dalszego aplikowania impulsów, $90 \%$ pozostałych szło w ich ślady ${ }^{25}$. Gdy nie było eksperymentatora nakazującego wymierzanie coraz silniejszych wstrząsów, niektórzy spośród badanych forsowali drzwi i spieszyli na pomoc „ofierze"26.

Dla sytuacjonistów ten $i$ inne eksperymenty $z$ zakresu psychologii społecznej dowodzą jednego: sytuacje wpływają na zachowanie silniej niż cechy. Harman dochodzi do wniosku ${ }^{27}$, że badania nie dostarczają nam żadnych racji, by wierzyć w istnienie cech globalnych i w to, że możemy stać się takimi ludźmi, jakimi zdaniem etyków cnoty powinniśmy się stać. Doris uważa, że dane te są zgodne $z$ faktem, iż niewielka liczba ludzi posiada cechy globalne, ale twierdzi, że „znaczna większość” dowodów wskazuje, iż cechy takie nie mają wiele wspólnego $z$ wywoływaniem zachowania ${ }^{28}$.

\section{Filozofia i psychologia kontratakuja}

Wielu filozofów i psychologów wysuwało argumenty podające w wątpliwość wnioski sytuacjonistów. Na przykład Rachana Kamtekar zarzuca im, że nie dostrzegają złożoności cnoty, a zwłaszcza tego, że cnotliwym działaniem kieruje rozsądek, który pozwala

24 J. Sabini, M. Silver, Lack of Character? Situationism Critiqued, „Ethics” I I5 (2005), s. 55I.

25 S. Milgram, The Individual in a Social World..., dz. cyt., s. Ii7; J. Sabini, M. Silver, Lack of Character?..., dz. cyt., s. 55I, przyp. 4I.

26 Tamże, przyp. 44.

27 G. Harman, Moral Philosophy Meets Social Psychology..., dz. cyt.

28 J.M. Doris, Lack of Character..., dz. cyt. 
swemu cnotliwemu posiadaczowi rozstrzygać, kiedy i jak działać29. Psychologowie Robert McCrae i Paul Costa Jr. zwracają uwagę, że rzadko zachodzi jednoznaczna odpowiedniość pomiędzy określonym zachowaniem i cechą, tak więc nawet występowanie zachowania, które zdaniem sytuacjonistów dowodziłoby istnienia cech globalnych (np. podniesienie upuszczonych dokumentów), nie musi być związane z cechą "pomocności”30.

Uważam, że ta krytyka sytuacjonizmu zmierza w dobrym kierunku. Poza komentarzami, które już poczyniłam odnośnie do badań nad efektem nastroju oraz kontynuacji eksperymentu Darleya i Batsona ${ }^{31}$, mam jeszcze kilka innych zatrzeżeń do sposobu wykorzystywania przez sytuacjonistów psychologii społecznej. Powołują się oni na jej badania, by przeforsować dwie tezy: I. sytuacje wpływają na zachowanie; 2 . cechy globalne, o ile istnieją, nie mają wielkiego wpływu na wywoływanie zachowania. Badania w dostatecznym stopniu dowiodły, że sytuacje wpływają na zachowanie; nie dowiodły natomiast (tak przynajmniej twierdzę), że cechy globalne nie istnieją, są rzadkie lub nie mają dużego wpływu na wywoływanie zachowania.

Powodem takiego stanu rzeczy jest to, że dowodu na istnienie cech globalnych sytuacjoniści oczekują od niewłaściwych badań badań, które stanowią dla mnie zaledwie „migawki” czy „urywki” długiej historii dociekań i eksperymentów z zakresu psychologii osobowości i psychologii społecznej. W I968 roku psycholog Walter Mischel opublikował Personality and Assessment, przełomową pracę, w której poddał krytyce dwa dominujące wówczas nurty psychologii: teorię cech i teorię stanów, zwaną również teorią psychodynamiczną. Stwierdził on ${ }^{32}$, że nie ma dowodu na istnienie cech, które wywoływałyby powtarzalne zachowanie w różnych sytuacjach. W następnych latach powstało mnóstwo

\footnotetext{
29 R. Kamtekar, Situationism and Virtue Ethics on the Content of Our Character, „Ethics” II4 (2004), s. 458-49I.

30 R.R. McCrae, P.T. Costa Jr., Toward a New Generation of Personality Theories: Theoretical Contexts for the Five-Factor Model [w:] J.S. Wiggins (ed.), The Five-Factor Model of Personality: Theoretical Perspectives, New York 1996, s. 5I-87.

31 J.M. Darley, D. Batson, From Jerusalem to Jericho..., dz. cyt.

32 W. Mischel, Personality and Assessment, New York 1968.
} 
badań poszukujących transsytuacyjnie powtarzalnego zachowania, które można by powiązać $z$ cechami. Niektóre $z$ badań przytaczanych przez sytuacjonistów (np. eksperymenty Hugh Hartshorne'a i Marka Maya ${ }^{33}$ czy Theodore'a Newcomba ${ }^{34}$ ) poprzedzają ten okres o cztery czy pięć dekad i były inspiracją dla poglądów Mischela. Poza nimi oraz badaniami nad efektem nastroju większość badań, na których opierają się sytuacjoniści, pochodzi $z$ lat 70 .

Na szczęście od tego czasu psychologia poszła naprzód. Przede wszystkim, teoria cech nie umarła z powodu krytyki ze strony psychologii społecznej. Żyje i ma się dobrze, lecz wiąże się z nią nader dużo szczegółowych teorii dotyczących natury cech, które nie wydają się szczególnie przydatne w dyskusji z sytuacjonistyczną krytyką etyki cnoty. Bardziej obiecującą koncepcję oferuje sam Mischel. W swojej pracy badawczej po roku I968 rozwinął on teorię cech w ramach szerszego, społeczno-poznawczego ujęcia osobowości. Odnalazł i sformułował empiryczny dowód "poznawczo-afektywnego systemu osobowości" (Cognitive-Affective Personality System; CAPS). Ujęcie to posłużyło mi do sformułowania teorii empirycznie ugruntowanych cech, do podzbioru których mogą należeć cnoty takie, jak rozumieli je etycy cnoty.

Zanim rozwinę tę koncepcje, poczynię jeszcze kilka obserwacji odnośnie do badań przywoływanych przez sytuacjonistów. Przede wszystkim sami psychologowie - autorzy tych badań - nie dochodzą do tych samych wniosków co sytuacjoniści. Najczęściej są oni ostrożni w ich formułowaniu i wyrażają zakłopotanie $z$ powodu uzyskanych wyników. Wielu z nich, jak na przykład Darley i Batson ${ }^{35}$ oraz Milgram ${ }^{36}$, zauważa, że aby zrozumieć zachowanie badanych, trzeba zbadać motywy i stany psychiczne, które za nim stoją. Innymi słowy, nie zadowalają się wygłaszaniem sytuacjonistycznej mantry „sytuacje wpływają na zachowa-

33 H. Hartshorne, M.A. May, Studies in the Nature of Character, Vol. 1: Studies in Deceit, New York 1928.

34 T.M. Newcomb, The Consistency of Certain Extrovert-Introvert Behavior Patterns in 51 Problem Boys, New York 1929.

35 J.M. Darley, D. Batson, From Jerusalem to Jericho..., dz. cyt.

36 S. Milgram, The Individual in a Social World..., dz. cyt. 
nie", lecz szukają zmiennych osobowościowych, które mogłyby wyjaśnić obserwowane zachowania. Tak więc zalecają wejrzenie w głąb podmiotu, tj. badanie jego stanów psychicznych, by zrozumieć jego zagadkowe zachowanie w określonych okolicznościach.

Sytuacjoniści oraz przywoływane przez nich badania przyjmują perspektywę "obserwatora” - w przeciwieństwie do perspektywy "podmiotu” - na sytuacje i powiązane z cechami zachowanie. Oznacza to, że to eksperymentator ocenia, co jest sytuacją, która ma wywołać zachowanie spowodowane przez daną cechę bądź $z$ nią powiązane. Co więcej, sytuacje, w jakich stawiani są uczestnicy badań, dają się obiektywnie opisać w kategoriach fizycznych właściwości środowiska - znalezienie dziesięciocentówki w aparacie telefonicznym, napotkanie leżącego i jęczącego człowieka czy otrzymanie polecenia opuszczenia ręki drugiej osoby na metalową płytkę. Zgodnie z przypuszczeniami Mischela i wynikami wywiadów $z$ badanymi przeprowadzanych po zakończeniu eksperymentów Darleya i Batsona oraz Milgrama na zachowanie badanych miało wpływ to, jak oni sami interpretowali dane sytuacje. Jeśli uczestnik badania nie będzie postrzegał danej sytuacji jako okazji do udzielenia komuś pomocy, nie udzieli jej. Może on posiadać cechę „pomocności”, ale skoro interpretuje on sytuację w innych kategoriach niż eksperymentator lub jest zdezorientowany i nie wie, co się dzieje, cecha ta nie zostaje aktywowana i nie pojawia się powiązane $z$ nią zachowanie.

Uświadomiwszy sobie, że to, co postrzegamy, ma znaczenie, powinniśmy dojść do wniosku (wraz z Mischelem), że psychologowie społeczni, którzy w latach 70. opisywali sytuacje w kategoriach czysto obiektywnych, przedstawiali ich zafałszowany obraz. By znaleźć dowód na transsytuacyjnie powtarzalne zachowanie powiązane z cechami, powinniśmy opisywać dane sytuacje w takich kategoriach, w jakich postrzegają je uczestnicy badań.

Właśnie tak zrobili Mischel i jego współpracownik, Yuichi Shoda. Badając dzieci uczestniczące w letnim obozie, opisywali sytuacje w kategoriach psychologicznie istotnych dla badanych, jak na przykład poczucie, że ktoś im grozi, dokucza czy udziela reprymendy. Obserwowali oni zachowanie dzieci w fizycznie różnych sytuacjach, na przykład w pracowni stolarskiej, podczas 
lunchu itp. Zauważyli, że transsytuacyjnie powtarzalne zachowanie nie było przypisane opisowi sytuacji w kategoriach fizycznych, lecz do ich subiektywnej interpretacji przez dzieci. Oznacza to, że pewne dzieci regularnie prezentowały ten sam rodzaj zachowania wtedy, gdy czuły się zagrożone, a inne wówczas, gdy czuły, że ktoś im dokucza lub ostrzega je. Zachowanie to było powtarzalne bez względu na fizyczne właściwości sytuacji, w których występowało. Obserwacje te umożliwiły badaczom przyporządkowanie dzieciom „profili osobowości” czy „sygnatur behawioralnych”. Owe „sygnatury behawioralne" miały postać zdań ,jeżeli, to...", na przykład "Jeżeli Johnny czuje, że inne dzieci dokuczają mu z powodu jego okularów, prawdopodobnie odpowie gniewem" lub "Jeżeli Lynn czuje, że została ostrzeżona przez dorosłego, prawdopodobnie zareaguje przestrachem".

Odkrycia te są dla mnie całkowicie zrozumiałe. Jeśli Johnny jest wrażliwy na punkcie swoich okularów i czuje, że ktoś mu dokucza, będzie skłonny reagować gniewem bez względu na to, czy znajduje się akurat w klasie, na stołówce czy na boisku szkolnym. W poszukiwaniu cech globalnych ważne jest psychologiczne znaczenie, jakie dana sytuacja ma dla ludzi, a nie jej fizyczne właściwości. Odkrycia Mischela i Shody odnośnie do transsytuacyjnie powtarzalnych zachowań leżą u podstaw przypisywania ludziom cech lokalnych, zwanych CAPS. W przeciwieństwie do przyjmowanych przez Dorisa cech lokalnych, które są przypisane dającym się obiektywnie opisać właściwościom sytuacji, cechy te są przypisane do znaczeń, jakie te sytuacje mają dla ludzi.

Z dotychczasowych rozważań płynie wniosek, że cechy CAPS są takim rodzajem cech, do podzbioru których będą się z dużym prawdopodobieństwem zaliczać cnoty (i wady). Jednakże Mischel i Shoda są ostrożni i nie chcą wyciągać wniosków wykraczających poza empiryczne dowody. Dlatego też nie twierdzą, że wykazane przez nich transsytuacyjnie powtarzalne zachowanie udowadnia istnienie cech globalnych. Ja jednak dowodziłam, że cechy CAPS, choć z początku mają charakter lokalny, dają się zgeneralizować i mogą stać się cechami globalnymi, ale nie jest to łatwy proces. Przypuśćmy na przykład, że cenię cechę współczucia, ale odkrywam, że przejawiam ją zazwyczaj jedynie w kontaktach $z$ małymi, 
słodkimi zwierzątkami. Przy pomocy refleksji i rozumu praktycznego mogę rozszerzyć zasięg swojego współczucia. Mogę zapytać sama siebie, czemu odczuwam współczucie wobec małych zwierząt, ale nie wobec innych ludzi, i odkryć, że moje współczucie wzbudzają zwierzęce słabości, ale nie zachodzi to w przypadku ludzkich słabości. By więc rozszerzyć zasięg swojego współczucia, postaram się zwracać większą uwagę na ludzkie słabości. Mogę oczywiście skorzystać $z$ innych strategii, ale chodzi mi tu o to, że na drodze refleksji mogę odkryć, czemu przejawiam (bądź nie) daną cnotę w określonej sytuacji, i ćwiczyć się w tych cnotach, które są dla mnie pożądane, a ograniczyć wady, których chcę się pozbyć.

Szczególną rolę w dostarczaniu strategii hamowania cech odgrywa psychologia uprzedzeń. Podobnie jak cechy, stereotypy to silnie zakorzenione konstrukty psychologiczne, aktywowane często w sposób automatyczny i bez udziału świadomości. Oznacza to, że określony bodziec, na przykład płeć czy kolor skóry, może uaktywnić stereotyp i nieświadomie wpłynąć na zachowanie. Czy można zahamować aktywowanie stereotypu lub też przeszkodzić czy zapobiec mu?

Psycholożki Patricia Devine i Margo Monteith twierdzą, że można. Porównują one hamowanie stereotypu do rzucania złego nawyku - prób zastąpienia złych reakcji kontrolowanymi przez podmiot dobrymi reakcjami, które zgadzają się z jego osobistymi standardami i przekonaniami ${ }^{37}$. Ci, którzy chcą "pozbyć się swojego nawyku", tzn. świadomie przyswoili sobie standardy nienacechowane uprzedzeniami i mają motywację, by postępować zgodnie z nimi, poddawani są działaniu zewnętrznych bodźców czy też czynników, które aktywują uprzednio przyswojony stereotyp. Mogą oni doświadczać poczucia winy z powodu rozdźwięku pomiędzy tymi nowymi standardami a własnymi reakcjami. Świadomość owego rozdźwięku nie tylko wywołuje negatywne uczucie wobec własnej osoby, lecz również wzmaga refleksyjną

37 P.G. Devine, Stereotypes and Prejudice: Their Automatic and Controlled Components, "Journal of Personality and Social Psychology" 56 (I989), s. I5. Zob. również P.G. Devine, A. Plant, B.M. Buswell, Breaking the Prejudice Habit: Progress and Obstacles [w:] S. Oskamp (ed.), Reducing Prejudice and Discrimination, Mahwah 2000. 
czujność i - co za tym idzie - wysiłki zmierzające do kontrolowania niepożądanych reakcji ${ }^{38}$.

Wyjaśniając bardziej szczegółowo, jak kontrolować automatyczne reakcje, Devine i Monteith korzystają z neuropsychologicznego modelu uczenia się i motywacji ${ }^{39}$. Zgodnie $z$ nim reakcja rozbieżna $z$ określonymi standardami powinna aktywować "system hamowania behawioralnego" (Behavioral Inbibition System; BIS). Uaktywnienie BIS skutkuje wzrostem pobudzenia i automatycznym, natychmiastowym przerwaniem zachowania. Następnie uwaga zostaje skierowana na sekwencję behawioralną, która doprowadziła do niepożądanej reakcji, tak by dana osoba mogła określić, co poszło nie tak. Osoba ta próbuje następnie zidentyfikować bodźce środowiskowe obecne podczas wystąpienia niepożądanej reakcji. W sytuacji idealnej dochodzi do skojarzenia tych czynników oraz samej reakcji z negatywnymi następstwami emocjonalnymi, takimi jak poczucie winy. W ten sposób, na drodze procesu nazwanego „refleksją retrospektywną”, można ustanowić sygnały kary (poczucie winy) ${ }^{40}$.

Działanie BIS i ustanowienie sygnałów kary są kluczowe w procesie pozbywania się nawykowego uprzedzenia. Gdy są już one ustanowione, w sytuacji kolejnego automatycznego uaktywniania stereotypu obecność podobnych sygnałów służy jako ostrzeżenie aktywujące BIS, co skutkuje wzrostem pobudzenia i spowolnieniem aktualnego zachowania. Pozwala to danej osobie postępować ostrożniej i przypomnieć sobie o osobistych przekonaniach, które mogą służyć za podstawę już nie automatycznych, lecz kontrolowanych reakcji na uaktywnienie stereotypu. Hamo-

38 P.G. Devine, M.J. Monteith, Automaticity and Control in Stereotyping [w:] S. Chaiken, Y. Trope (eds.), Dual-Process Theories in Social Psychology, New York 1999, s. 352-353.

39 Tamże, s. 353; M.J. Monteith, Self-Regulation of Prejudiced Responses: Implications for Progress in Prejudice Reduction Efforts, "Journal of Personality and Social Psychology" 65 (I993), s. 470-47I i 477; J.A. Gray, N. McNaughton, The Neuropsychology of Anxiety: An Enquiry into the Functions of the Septo-Hippocampal System, New York 2000.

40 Zob. P.G. Devine, M.J. Monteith, Automaticity and Control in Stereotyping, dz.cyt., s. 353 . 
wanie cech niegodziwych i związanego $z$ nimi zachowania może przebiegać bardzo podobnie.

W powyższym opisie chciałam pokazać, że rozwój bądź hamowanie cech CAPS może przebiegać bardzo podobnie do rozwoju charakteru według modelu etyki cnoty. Zgodnie z pierwszą częścią tej koncepcji, zarysowaną na przykładzie świadomych prób rozciągnięcia współczucia z małych zwierząt na wszystkich ludzi, do rozwijania charakteru potrzebny jest rozmyślny wybór działania. Zgodnie z częścią drugą, korzystającą z modelu niwelowania stereotypu do zilustrowania procesu niwelowania bądź kontrolowania wady, rozwój charakteru odbywa się na drodze częściowo automatycznych, a częściowo kontrolowanych procesów poznawczych.

Automatyczne procesy poznawcze przebiegają zazwyczaj poniżej poziomu świadomości, w przeciwieństwie do procesów kontrolowanych, których jesteśmy świadomi. Połączenie tych dwóch rodzajów procesów tłumaczy nawyk cnotliwego działania. Nabywanie nawyków to oczywiście trzeci sposób kształtowania się charakteru. W dalszej części zarysuję koncepcję formowania charakteru na drodze nawykowych działań zależnych od celu. Wyjaśnia ona, jak cnota może rozwinąć się jako coś w rodzaju „drugiej natury” i jak teoria "drugiej natury” jest formą ustosunkowania się do racji.

Na początek wyjaśnię bardziej szczegółowo procesy kontrolowane i automatyczne. Teoria podwójnych procesów w psychologii poznawczej i społecznej twierdzi, że pracę umysłu można wyjaśnić w kategoriach tych dwóch procesów poznawczych. Oto jakie kryteria, muszą spełniać procesy kontrolowane:

I. muszą przebiegać pod celową kontrolą podmiotu, a tym samym być obecne w jego świadomości;

2. muszą cechować się elastycznością lub być podatne na interwencje podmiotu;

3. i są ograniczone poziomem świadomej uwagi dostępnej jednostce w określonym czasie ${ }^{41}$.

41 J.A. BARgh, Conditional Automaticity: Varieties of Automatic Influence in Social Perception and Cognition [w:] J.S. Uleman, J.A. Bargh (eds.), Unintended Thoughts, New York 1989, s. 3-4. 
A oto kryteria procesów automatycznych:

I. są niecelowe, tzn. pojawiają się nawet pomimo braku wyraźnych zamiarów bądź celów;

2. są niezależne od woli;

3. przebiegają poza świadomością;

4. są autonomiczne bądź mogą dobiec do końca bez świadomej interwencji podmiotu;

5. nie są zapoczątkowywane przez świadomy wybór bądź wolę podmiotu;

6. nie wymagają wysiłku, tzn. przebiegają nawet wtedy, gdy zasoby uwagi są ograniczone ${ }^{42}$.

Rozmyślne bądź celowe działania są wynikiem procesów kontrolowanych. Regularnie powtarzane działania, które wchodzą w nawyk, jak na przykład pisanie na komputerze czy jazda samochodem znaną trasą, stanowią przykłady działania procesów automatycznych. Zdaniem psychologów procesy poznawcze spełniają „większość bądź wszystkie” spośród odpowiednich kryteriów. Wiele działań zdaje się być wynikiem połączenia obu rodzajów procesów.

Istnieją różne rodzaje czynności automatycznych. Ten, który nas tutaj interesuje, to czynności automatyczne zależne od celu. Przykłady stanowią nawykowe pisanie na komputerze czy jazda samochodem znaną trasą - spełniają one kryterium dobrowolnego zapoczątkowania działania przez podmiot, który dąży do określonego celu, oraz kryterium możliwości ingerowania w ten proces i przerwania go.

Jak przebiegają czynności automatyczne zależne od celu? John Bargh, znany badacz tematu, wysunął hipotezę, że działanie skierowane na cel można wywołać poprzez wielokrotne aktywowanie przez podmiot przedstawienia jego trwale posiadanego celu. Cel, którego przedstawienie jest często aktywowane przez odpowiednie bodźce, staje się trwale dostępny, tj. łatwy do aktywowania. W czynnościach automatycznych zależnych od celu aktywacja celu przebiega poza świadomością podmiotu, pod wpływem dzia-

42 Tamże, s. 3 i 5 . 
łania czynników wyzwalających ${ }^{43}$. Bargh i jego współpracownicy zwrócili szczególną uwagę na główny sposób, w który bodźce środowiskowe mogą aktywować przedstawienia trwałych celów: częste i konsekwentne łączenie cech sytuacyjnych ze skierowanymi na cel zachowaniami prowadzi do rozwoju trwałych powiązań sytuacja - przedstawienie ${ }^{44}$. Tak jak inne przedstawienia, cele i zamiary są przechowywane w pamięci i mogą być aktywowane przez bodźce środowiskowe. Przedstawienia trwałych celów mogaz być w powtarzalny sposób aktywowane w tego samego rodzaju sytuacjach, tak że skojarzenie w umyśle cech sytuacyjnych i działania skierowanego na cel staje się automatyczne. Gdy dana osoba znajdzie się w sytuacji o określonych właściwościach, wyobrażenie skojarzonego $z$ nią celu zostanie aktywowane natychmiast, choć w sposób nieświadomy. Z kolei to aktywowane wyobrażenie uruchamia plany, zmierzające do osiągnięcia celu, które zmieniają się elastycznie, w interakcji ze zmiennymi danymi dostarczanymi przez środowisko ${ }^{45}$. Badacze zajmujący się czynnościami automatycznymi zgadzają się, że zachowania skierowane na cel, aktywowane w sposób nieświadomy, nie są odruchowymi reakcjami na bodźce, lecz inteligentnymi, elastycznymi odpowiedziami na zmieniające się sygnały środowiskowe i wykazują wiele wspólnych cech $z$ działaniami podejmowanymi świadomie ${ }^{46}$.

Bargh i jego współpracownicy zidentyfikowali cele, które mogą $z$ dużym prawdopodobieństwem być trwałe i których przedstawie-

43 J.A. BArgh i in., The Automated Will: Nonconscious Activation and Pursuit of Behavioral Goals, "Journal of Personality and Social Psychology” 8I (200I), s. I024; T.L. Chartrand, J.A. Bargh, Automatic Activation of Impression Formation and Memorization Goals: Nonconscious Goal Priming Reproduces Effects of Explicit Task Instructions, "Journal of Personality and Social Psychology" 7I (I996), s. 465.

44 Tamże; J.A. Bargh, P.M. Gollwitzer, Environmental Control of Goal-Directed Action: Automatic and Strategic Contingencies Between Situation and Behavior [w:] W.D. Spaulding (ed.), Integrative Views of Motivation, Cognition, and Emotion, Lincoln 1994, s. 72; J.A. BARgh i in., The Automated Will..., dz. cyt., s. I0I5.

45 T.L. Chartrand, J.A. Bargh, Automatic Activation..., dz. cyt., s. 465; J.A. Bargh, M. Ferguson, Beyond Behaviorism: On the Automaticity of Higher Mental Processes, „Psychological Bulletin” I26 (2000), s. 932 i nn.

46 A. Bargh i in., The Automated Will..., dz. cyt, s. I0I4-IoI5 i 1025. 
nia w umyśle mogą być aktywowane automatycznie ${ }^{47}$. Należą do nich cele związane $z$ wartościami, takie jak dążenie do równości w wymianie społecznej i zobowiązanie do mówienia prawdy. Te cele i zobowiązania mogą wyrażać się w różnego rodzaju działaniach podejmowanych w obiektywnie różnych sytuacjach ${ }^{48}$. Odkrycie, że cele związane $z$ wartościami przejawiające się w obiektywnie różnych rodzajach sytuacji, w tym w interakcjach interpersonalnych, są trwałe i przez to mogą $z$ dużym prawdopodobieństwem zostać aktywowane automatycznie, sugeruje, że cele związane $z$ cnotami również mogą być trwałe i aktywowane automatycznie w obiektywnie różnych rodzajach sytuacji. Jeśli ktoś ma trwały cel związany z cnotą, jak na przykład bycie człowiekiem sprawiedliwym, jego konsekwentne dążenie do tego celu może dać początek różnego rodzaju sprawiedliwym działaniom, odpowiednim do obiektywnie różnych okoliczności. Jeśli ktoś wielokrotnie napotyka okoliczności wymagające sprawiedliwej reakcji, jego sprawiedliwe działania mogą $\mathrm{w}$ końcu być uruchamiane przez sygnały sytuacyjne poza jego świadomością. Jego sprawiedliwe działania mogą stać się nawykowe, a są to tego rodzaju działania, które z czasem mogą wytworzyć dyspozycje do sprawiedliwego zachowania.

Rzućmy nieco więcej światła na ten obraz. Zdefiniowałam "cel związany z cnotą" jako taki cel, który - gdyby został obrany przez podmiot - mógłby w odpowiednich warunkach doprowadzić do podjęcia przez ów podmiot cnotliwych działań. Zamierzone oraz niezamierzone cnotliwe postępowanie nawykowe może wynikać $z$ obrania przez podmiot celu związanego $z$ cnotą. Przez „odpowiednie warunki” rozumiem występowanie bodźców środowiskowych, które uaktywniają przedstawiony cel, oraz nieobecność bądź nieskuteczność czynników powstrzymujących od działania. Z tej definicji wynika, że podmiot nie musi obrać za cel bycia cnotliwym człowiekiem tout court, lub choćby w sensie

47 J.A. BArgh, Auto-Motives Preconscious Determinants of Social Interaction [w: ] E.T. Higgins, R.M. Sorrentino (eds.), Handbook of Motivation and Cognition: Foundations of Social Behavior, New York 1990, s. III-II9; J.A. BARgh, P.M. Gollwitzer, Enviromental Control of Goal-Directed Action..., dz. cyt., s. 78-79. 
posiadania jakiejś określonej cnoty, na przykład cierpliwości czy odwagi - inne cele również mogą prowadzić go do cnotliwych działań. Ktoś może obrać sobie za cel bycie dobrym rodzicem, kolegą, pielęgniarką, obywatelem czy przyjacielem. Obranie takich celów również może prowadzić do cnotliwego postępowania, ponieważ pełnienie tych ról wiąże się z określonymi cnotami. Cele niesienia pomocy innym, wspierania pokoju czy bycia uczciwym, przyzwoitym człowiekiem również są związane $z$ cnotą $w$ tym sensie, że obranie ich prowadzi do cnotliwego postępowania.

Lecz takie ujęcie zdaje się przypominać błędne koło: działanie jest cnotliwe wówczas, gdy wyraża cnotliwą motywację. By go uniknąć, musimy przeprowadzić rozróżnienie pomiędzy cnotliwym postępowaniem, które jedynie wyraża cnotliwą motywację, a prawdziwie bądź czysto cnotliwym postępowaniem, które zarówno wyraża cnotliwe motywy, jak i skutecznie utrafia w cel cnoty, ponieważ zakłada rozsądek. Prawdziwie cnotliwe działania trafiają w cel cnoty, gdyż wypływają z dążenia do doskonałości bądź z rozsąadku, a nie są dziełem przypadku czy szczęśliwego trafu. Dążenie do doskonałości może zostać skanalizowane w czysto cnotliwych nawykowych działaniach; przez tę nawykowość nie staje się ono w mniejszym stopniu rozsądne.

Czy przypisanie komuś celu związanego z cnotą jest konieczne, by wyjaśnić jego nawykowe cnotliwe działania? Uważam, że tak. By to zrozumieć, przyjrzyjmy się przykładowi Tima, który w przeszłości podejmował nawykowo cnotliwe działania. Z historii jego życia możemy wnioskować, że jest on nawykowo sprawiedliwy. Czy musimy posuwać się dalej i dodatkowo stwierdzić, że obrał on sobie za cel bycie sprawiedliwym? Co wnosi obranie takiego celu? Jeśli nie mówi nam ono o cnotliwości nawykowych działań Tima nic, czego nie moglibyśmy wywnioskować z samych tych działań, to obranie celu związanego $z$ cnotą nie jest koniecznym warunkiem nawykowego cnotliwego postępowania.

Uważam, że aby rzetelnie stwierdzić, iż Tim jest prawdziwie cnotliwy, potrzebujemy więcej informacji niż tylko tych, których dostarcza nam wiedza o jego nawykowych cnotliwych działaniach. Musimy znać charakter jego motywacji. Przypuśćmy, że Tim zdaje się być nawykowo sprawiedliwy tylko dlatego, że chce być 
jak jego ojciec, który jest prawdziwie sprawiedliwym człowiekiem. Tim nie obrał sobie za cel bycia sprawiedliwym czy uczciwym człowiekiem, leczy bycie takim jak jego ojciec. Gdyby on był niesprawiedliwy, Tim również byłby niesprawiedliwy. Cel stania się takim jak ojciec zdaje się prowadzić do nawykowego podejmowania cnotliwych działań. Nie chciałabym jednak twierdzić, że Tim nie jest prawdziwie sprawiedliwy na tej podstawie, że jego rzekomo sprawiedliwe postępowanie wynika $z$ niewłaściwych powodów. Zwróćmy również uwagę, że motywacja Tima może być pofragmentowana - być może w różnych sytuacjach za jego nawykowymi sprawiedliwymi działaniami stoją różne struktury psychologiczne. Również w takim przypadku wnioskowanie $z$ nawykowych działań Tima o jego cnotliwej dyspozycji byłoby błędne, gdyż brak byłoby spójnej psychologicznej struktury, którą można by określić jako cnotę w tradycyjnym sensie.

Podsumowując, według ujęcia automatycznościowego posiadanie przez podmiot trwale dostępnego przedstawienia celu związanego $z$ cnota jest koniecznym, ale niewystarczającym warunkiem podejmowania nawykowo cnotliwych działań. Cele związane $z$ cnotą dają się łatwo zanalizować w kategoriach przekonań i pragnień podmiotu: przekonań dotyczących wymagań wiążących się $z$ cnotą w ogóle i w konkretnych sytuacjach oraz pragnień bądź zobowiązań do wytrwania w cnotliwym postępowaniu. Dlatego też zależne od celu nawyki są istotowo powiązane ze stanami psychicznymi podmiotu. Jego związane $z$ cnotą cele dostarczają motywów do podejmowania nawykowych cnotliwych działań oraz ich racjonalnego wyjaśnienia. To, że do niektórych cnotliwych działań jesteśmy pobudzani nieświadomie i podejmujemy je nawykowo, w dużej mierze bez udziału świadomości, wyjaśnia, dlaczego wykonujemy je bez wysiłku i pozornie bez potrzeby skupiania uwagi czy wyraźnego namysłu. Nasze cele są nieświadomie aktywowane przez czynniki sytuacyjne. Sekwencje naszych działań rozwijają się w sposób elastyczny i inteligentny $z$ chwili na chwilę w odpowiedzi na informacje otrzymywane ze środowiska, bez potrzeby świadomego rejestrowania przez nas wszystkich wskazówek i reakcji. Automatycznościowe ujęcie nawykowych cnotliwych działań dostarcza głębokiego wyjaśnienia cnotliwej 
praktyki i tłumaczy - w kategoriach głęboko zakorzenionych procesów poznawczych i motywacyjnych - jak i dlaczego cnota może „wejść w krew” bądź stać się „drugą naturą"49. Koncepcja automatyczności nie kwestionuje ani nie zastępuje, lecz raczej uzupełnia teorie tłumaczące cnotliwe postępowanie w kategoriach świadomego bądź powierzchownego namysłu i wyboru. Tłumaczy również, w jaki sposób cnota może stać się „drugą naturą", a zarazem podlegać wpływowi rzeczywistych wydarzeń dostarczających powodów do cnotliwych działań.

W dotychczasowej dyskusji zajęłam się „pierwszą falą” sytuacjonistycznych ataków na etykę cnoty, tj. zarzutami pod adresem cech globalnych. W odpowiedzi na nie odwołałam się do dorobku empirycznej psychologii, dowodząc, że cnoty mogą z dużym prawdopodobieństwem stanowić podzbiór udokumentowanych empirycznie cech CAPS, i kreśląc w zarysie wyjaśnienie, w jaki sposób możemy rozwinąć cnoty poprzez rozmyślne wybory i nawykowe podejmowanie działań służących związanym z cnotą celom. Odpowiedź ta jest przedmiotem mojej książki Virtue as Social Intelligence: An Empirically Grounded Theory. Jej celem, jak również celem przygotowywanych obecnie prac, jest pokazanie, że sytuacjoniści przedwcześnie odrzucają możliwość empirycznego ugruntowania cech globalnych i oferują jednostronny obraz poznania. Wbrew ich twierdzeniom uważam, że znaczna część współczesnej psychologii empirycznej jest zgodna - w głównej mierze $-z$ Arystotelesowskim ujęciem charakteru, cnoty i działania, a tym samym może dostarczyć dla niego poparcia. W kolejnych dwóch częściach odwołam się do bardziej współczesnej pracy (ukaże się w The Handbook of Virtue Ethics pod redakacją Stana van Hoofta), w której przedstawiam drugą falę sytuacjonistycznej krytyki i jej możliwe odparcie.

49 R. Hursthouse, On Virtue Ethics, Oxford I999; J. McDowell, Two Sorts of Naturalism, dz. cyt., s. I49-I79. 


\section{Syłuacjonistyczna krytyka jedności poznania}

Niektórzy filozofowie dowodzą, że charakter nie jest tak pofragmentowany, jak twierdzą sytuacjoniści. Jest tak dlatego, że rozum praktyczny umożliwia nam uświadomienie sobie oddziałujących na nas sił sytuacyjnych, namysł nad ich wartością i podejmowanie celowych wyborów co do sposobu postępowania ${ }^{50}$. Merritt, Doris i Harman krytykują twierdzenie, że rozum praktyczny może spełniać funkcję integrującą, mówiąc, iż „zgodnie $z$ badaniami empirycznymi rozum podlega wpływom sytuacyjnym w nie mniejszym stopniu niż widoczne zachowanie; musimy liczyć się $z$ tym, że pojęcia racjonalności używane w tradycyjnych koncepcjach charakteru same są empirycznie nieadekwatne" ${ }^{\prime \prime}$.

By uzasadnić swoją tezę, zestawiają oni ze sobą dwie koncepcje roli rozumu w życiu moralnym: tę przyjmowaną przez etyków cnoty, w myśl której zachowaniem kieruje racjonalny namysł, i tę przyjmowaną przez nauki kognitywne. By wyjaśnić tę ostatnią, przywołują oni "teorie podwójnego procesu” dotyczące poznania. Jak widzieliśmy, teorie te utrzymują, że dysponujemy dwoma sposobami poznania: kontrolowanym i automatycznym. Autorzy słusznie przestrzegają przed mylnym pojmowaniem procesów kontrolowanych i automatycznych jako dwóch wzajemnie się wykluczających kategorii ${ }^{52}$. Większość działań to złożone połączenia tych dwóch rodzajów procesów. Zgodnie $z$ koncepcjami poznania przyjmowanymi przez nauki kognitywne autorzy podkreślają wszechobecność procesów przebiegających poniżej poziomu świadomości. W przeciwieństwie do teorii etyki cnoty, w myśl których naszymi celowymi działaniami kieruje racjonalny namysł, w obrazie kreślonym przez Merritt, Dorisa i Harmana zachowanie jest często odpowiedzią na bodźce, których nie

50 R. Kamtekar, Situationism and Virtue Ethics..., dz. cyt.; J. Annas, Intelligent Virtue, dz. cyt.

51 M.W. Merritt, J.M. Doris, G. Harman, Character, dz. cyt., s. 360.

52 Tamże, s. 372. 
jesteśmy świadomi, i przez to nie podlega i nie może podlegać naszej kontroli.

Merritt, Doris i Harman przyjmują koncepcję nauk kognitywnych, by wyjaśnić zachowania niektórych badanych w eksperymentach sytuacjonistycznych. Zwracają uwagę, że niektórzy badani doświadczają zjawiska zwanego przez nich moralną dysocjacją ${ }^{53}$, tj. angażują się w zachowanie, które narusza przyjmowane przez nich - jak mogłoby się zdawać - normy. Autorzy utrzymują, że zachowanie to jest wywołane przez tendencje do reakcji zdepersonalizowanych, tj. tendencje do reagowania na czynniki sytuacyjne oddziałujące poniżej poziomu świadomości ${ }^{54}$. Szczególną postacią moralnej dysocjacji jest inkongruencja ${ }^{55}$. Pojawia się ona wówczas, gdy za danym zachowaniem stoją nieświadome procesy, których nie uznalibyśmy za powody do działania zgodnego $z$ naszymi normatywnymi zobowiązaniami ${ }^{56}$. Gdybyśmy byli świadomi, że u źródeł tego zachowania leżą nieświadome procesy, potępilibyśmy je. Inkongruencja „narusza pojęcie solidnie zintegrowanego namysłu" ${ }^{7}$.

Merritt, Doris i Harman ilustrują działanie nieświadomego umysłu, a tym samym - jak uważają - zakłócenie funkcjonowania rozumu praktycznego licznymi badaniami $z \mathrm{~d} z$ iedziny psychologii społecznej. Na przykład wstępnie zaktywizowane zachowania są wynikiem tendencji do reakcji zdepersonalizowanych. Obserwowano, że badani poddani aktywizacji wstępnej za pomocą takich słów jak „starszy” czy „bingo”, ukrytych w zakodowanych zdaniach, wolniej podchodzili do windy niż badani z grupy kontrolnej58. Badania nad aktywizacją wstępną i wiele innych pokazują, że na zachowanie często wpływają czynniki oddziałujące na nas poniżej poziomu świadomości. Jeśli jednak przyjmiemy, że wolne chodzenie nie narusza niczyich przekonań moralnych, badania

Tamże, s. 363 .

Tamże, s. 370-37I.

Dziękuję Johnowi M. Dorisowi za wyjaśnienie zależności pomiędzy dysocjacją moralną a inkongruencją (prywatny mail z 2 stycznia 20I2).

M.W. Merritt, J.M. Doris, G. Harman, Character, dz. cyt., s. 375.

Tamże.

58

Tamże, s. 374 . 
nad aktywizacją wstępną, takie jak przywołane powyżej, pokazują również, że tendencje do reakcji zdepersonalizowanych nie muszą prowadzić do moralnej dysocjacji czy inkongruencji. Inne badania mają bardziej bezpośrednie następstwa dla moralności. Autorzy zwracają uwagę, że niektórzy uczestnicy badań, takich jak te przeprowadzone przez Bibba Latanégo i Johna Darleya ${ }^{59}$, zaprzeczali, jakoby obecność innych ludzi powstrzymała ich przed udzieleniem pomocy potrzebującemu, nawet wówczas, gdy przedstawiono im empiryczne dowody ${ }^{60}$. Literatura poświęcona stereotypom społecznym również dostarcza nam istotnych $z$ moralnego punktu widzenia przykładów wpływu nieuświadomionych czynników na nasze zachowanie, potwierdzając występowanie negatywnych reakcji wywołanych rasą, płcią $\mathrm{i}$ innymi czynnikami, które byśmy prawdopodobnie potępili, gdybyśmy o nich wiedzieli ${ }^{61}$. Argumentację sytuacjonistów uzupełnia jeszcze jeden element: nieuświadomione czynniki rozpraszają naszą uwagę skierowaną na innych i robią to na różne sposoby naruszające nakazy racjonalnego, moralnego namysłu. Niepokojące jest to, że owe nieuświadomione czynniki kierują naszą moralną uwagę w złą stronę, przez co skupiamy się na nieistotnych bądź mało ważnych $z$ moralnego punktu widzenia aspektach sytuacji, przeoczając tym samym okazje, w których oczekuje się od nas moralnego działania skierowanego na innych, jak na przykład zapobieżenia krzywdzie czy udzielenia pomocy.

Nie jest to pozbawione sensu jako częściowe wyjaśnienie zachowania uczestników eksperymentów z zakresu psychologii społecznej62. Nasi krytycy idą jednak dalej: „W tym stopniu, w jakim automatyzm jest powszechny, model praktycznej racjonalności proponowany przez etykę cnoty staje się problematyczny"63. Prezentowane przez trójkę autorów wyjaśnienie zachowania badanych może być prawdziwe, ale ich krytyka spójności poznania

59 B. Latané, J.M. Darley, The Unresponsive Bystander: Why Doesn't He Help?, Englewood Cliffs I970, s. I24.

60 M.W. Merritt, J.M. Doris, G. Harman, Character, dz. cyt., s. 373.

61 Tamże, s. 375.

62 Autorzy nie próbują udzielić kompletnego wyjaśnienia (tamże, s. 37I).

63 Tamże, s. 375. 
i roli praktycznej racjonalności w życiu moralnym idzie zbyt daleko. Nie wszystkie nieuświadomione czynniki muszą rozpraszać słuszną moralnie uwagę skierowaną na innych; niektóre wzmagają naszą moralną czujność i inne zdolności moralne. Te aspekty automatyczności umożliwiają nakreślenie bardziej spójnego obrazu świadomego i nieświadomego poznania, obrazu bardziej przychylnego stanowisku etyki cnoty w kwestii roli i prymatu praktycznego rozumu w naszym życiu moralnym.

\section{W kierunku bardziej ujednoliconego ujęcia procesów poznawczych}

\subsection{Zakorzenione konstrukty psychologiczne}

Wiele badań psychologicznych łagodzi podejście sytuacjonistów. Widzieliśmy już, jak zależny od celu automatyzm może działać poniżej poziomu świadomości, dając początek nawykowemu działaniu zmierzającemu do trwałych celów związanych z cnotą. Dodatkowo Daniel Lapsley i Patrick Hill ${ }^{64}$ rozwijają społeczno-poznawczą teorię osobowości moralnej, która najważniejsze miejsce przyznaje schematom moralnym. Schematy to "struktury wiedzy ogólnej, które porządkują informacje, oczekiwania i doświadczenie"65. Ich zdaniem osobowość moralna jest zunifikowana i daje się wytłumaczyć stałą dostępnością moralnych schematów danej osoby. Innymi słowy, struktury wiedzy ogólnej, funkcjonujące w obrębie psychologicznej gospodarki jednostki, dostarczają epistemicznej otwartości na przetwarzanie określonego rodzaju informacji. Na przykład człowiek dysponujący właściwymi schematami moralnymi będzie bardziej skłonny zauważyć cierpiącą osobę i odpowiednio na nią zareagować, niż ktoś, kto tych schematów

64 D.K. Lapsley, P.L. Hill, On Dual-Processing and Heuristic Approaches to Moral Cognition, „Journal of Moral Education” 37 (2008), s. 313-332.

65 Tamże, s. 322. 
nie posiada. Wielokrotne przetwarzanie określonego rodzaju informacji zwiększa siłę i wyrazistość odpowiednich schematów moralnych. Internalizacja bądź brak właściwych schematów moralnych może wyjaśnić niektóre spośród różnych wariantów zachowań w badaniach sytuacjonistów, takich jak słynny eksperyment Darleya i Batsona z dobrym Samarytaninem, w którym badani, spiesząc się na wygłoszenie referatu, mijali leżącego na ziemi i najwyraźniej potrzebującego pomocy asystenta eksperymentatora. Ci, którzy posiadają schemat "człowieka w potrzebie”, mogli spostrzec „ofiarę" i zareagować na nią inaczej niż ci, którzy posiadają schemat "pijanego natręta”. W takich przypadkach procesy poznawcze pośredniczące $w$ moralnych działaniach znajdują się pod wpływem struktur moralno-poznawczych, a internalizacja tych struktur jest stabilnym elementem osobowości, który - funkcjonując poniżej poziomu świadomości - kieruje naszą uwagę moralną we właściwą stronę i ułatwia nam przez to moralne działanie.

Badania nad sytuacyjną aktywizacją wstępną, aktywowaniem stereotypów, schematami moralnymi i automatyzmem zależnym od celu stanowią przedmiot żywej i rozległej literatury psychologicznej dotyczącej funkcjonowania nieświadomego umysłu ${ }^{66}$. Choć niektóre spośród tych badań dostarczają poparcia dla argumentów Merritt, Dorisa i Harmana na rzecz fragmentaryzacji poznania, to $z$ wielu wyłania się bardziej zunifikowany obraz, w którym procesy świadome i nieświadome przebiegają razem, pełniąc adaptacyjną funkcję organizmu. Działanie umysłu jest zunifikowane, by umożliwić organizmowi funkcjonowanie w złożonym środowisku bez obciążania koniecznością ciągłego świadomego przetwarzania napływających bodźców. $Z$ tego punktu widzenia rozważna racjonalność wydaje się wierzchołkiem sporej góry lodowej, w której nieświadome procesy psychiczne zwykle, choć nie zawsze, wspierają nasze wybory. To, że owe nieświadome procesy niekiedy sprzeciwiają się naszym normatywnym zobowiązaniom,

66 J.A. BArgh (ed.), Social Psychology and the Unconscious: The Automaticity of Higher Mental Processes, New York 2007; R.R. Hassin, J.S. Uleman, J.A. BARgh, The New Unconscious, New York 2005. 
w niczym nie umniejsza możliwości użycia rozumu praktycznego. Potęga praktycznej racjonalności opiera się w dużej mierze, choć nie wyłącznie, na jej potencjale do kształtowania nieświadomych procesów psychicznych w taki sposób, by zwiększyć naszą zdolność do przyswojenia, zachowania, wykorzystania i rozszerzenia tego, co wiemy. Teorie te stanowią część fascynującej linii obrony przeciw zarzutom sytuacjonistów skierowanym w cechy i poznanie, jaką można znaleźć w pracach etyków cnoty i psychologów zajmujących się rozwojem cnoty.

\subsection{Rozwój cnoty: zbieżność perspektywy filozoficznej i psychologicznej}

Edward Slingerland, dla przykładu, dowodzi, że wczesnokonfucjańska etyka cnót unika ostrza większości spośród sytuacjonistycznych zarzutów ${ }^{67}$. Twierdzi on, że rozwój i modyfikacja cnót w ujęciu wczesnokonfucjańskiego filozofa Mencjusza są podobne do koncepcji kultywowania cnoty zaproponowanej przeze mnie, w myśl której cnoty można rozmyślnie rozwijać zgodnie $z$ wartościami jednostki ${ }^{68}$. Slingerland dodaje pomysł, że konfucjańskie kultywowanie cnoty przebiegało pod kierunkiem doświadczonego nauczyciela; pomysł ten można znaleźć również u Annas ${ }^{69}$. Slingerland opisuje wykorzystywanie sytuacji do kultywowania cnoty i zwraca uwagę na trening rytuałów oraz inne formy modyfikacji zachowania (np. oddawanie się różnym aktywnościom kulturalnym) jako istotne w procesie nabywania cnoty ${ }^{70}$. Studiowanie tekstów Konfucjusza, zawierających opisy mędrców godnych naśladowania, nazywa „rodzajem zawsze dostępnej pojęciowej aktywizacji wstępnej"ㄱ. Wreszcie w kategoriach przypominających schema-

67 E. Slingerland, The Situationist Critique and Early Confucian Virtue Ethics, "Ethics” I2I (20II), s. 390-4I9. Zob. również D.S. Mower, Situationism and Confucian Virtue Ethics, „Ethical Theory and Moral Practice” I6 (2013), s. II3-I37.

Zob. N. Snow, Virtue as Social Intelligence..., dz. cyt.

69 J. Annas, Intelligent Virtue, dz. cyt.

70 E. Slingerland, The Situationist Critique..., dz. cyt., s. 404 i nn.

71 Tamże, s. 4I2. 
ty moralne i automatyzm zależny od celu sugeruje on, że sposób interpretacji konfucjańskiej etyki cnoty jest „rodzajem »opóźnionej« kontroli poznawczej funkcjonującej poprzez zaszczepianie pragnień i celów $z$ wyższego poziomu w znajdujących się na niższym poziomie systemach emocjonalnych i motosensorycznych"72.

Annas również kładzie nacisk na nabywanie cnoty ${ }^{73}$. W jej koncepcji najważniejsze są dwa kluczowe twierdzenia: że cnota jest jak zdolność praktyczna i w swojej istocie dynamiczna, znajduje się w ciągłym rozwoju. To drugie twierdzenie występuje również w konfucjańskiej etyce cnoty ${ }^{74}$. Inspirując się antyczną filozofią Zachodu, badaczka dowodzi, że szukając wskazówek, jak rozwijać cnoty, powinniśmy przyjrzeć się rozwojowi umiejętności praktycznych. Cnoty, podobnie jak umiejętności praktyczne, powinny być z rozmysłem rozwijane. Rozwój ten wymaga od ucznia podwójnej motywacji: potrzeby nauki i ambicji ${ }^{75}$. Pilny uczeń stara się zrozumieć, co robi jego nauczyciel, nie zadowalając się po prostu jego naśladowaniem - pragnie dowiedzieć się czegoś więcej i osiągnąć to dla siebie. W obu tych motywacjach w wyraźny sposób zawierają się poznanie i rozumowanie praktyczne. Rozumowanie praktyczne odgrywa jeszcze inne role w teorii Annas. Przykładowo, do nauczania i uczenia się cnót potrzebna jest umiejętność mowy ${ }^{76}$. Jak mistrz danej umiejętności praktycznej musi być w stanie wytłumaczyć uczniowi, co i dlaczego robi, tak i nauczyciel cnoty musi umieć wyjaśnić swojemu podopiecznemu, co to znaczy być odważnym czy szczodrym i dlaczego jest to ważne. Również uczniowie muszą być w stanie korzystać z rozumowania praktycznego na różne skomplikowane i wysoce zindywidualizowane sposoby. W teorii Annas ważne jest to, że uczymy się, działając w określony sposób. Choć możemy powtarzać działania związane $z$ daną umiejętnością bądź cnotą, by dobrze je opanować, to przyswojenie sobie cnotliwych reakcji

Tamże, s. 4I6.

J. Annas, Intelligent Virtue, dz. cyt.

74 E. Slingerland, The Situationist Critique..., dz. cyt., s. 404 oraz 4I3-4I4.

75 J. Annas, Intelligent Virtue, dz. cyt., s. I6 i nn.

76 Tamże, s. I9. 
wymaga inteligencji, a nie nauki na pamięć $c^{77}$. Cnotliwe dyspozycje, podobnie jak umiejętności praktyczne, nabywa się i rozwija na drodze inteligentnego i elastycznego przyzwyczajenia, a nie bezmyślnej rutyny.

Empiryczne dowody pewnych aspektów tej filozoficznej teorii nabywania cnót znajdujemy w pracy Darcii Narvaez i Daniela Lapsleya ${ }^{78}$. Po pierwsze, ich podejście przyznaje pewną rolę cichemu bądź nieświadomemu przetwarzaniu informacji w procesie uczenia się, w tym różnym rodzajom automatyzmu, które rozwijają się po pojawieniu się rozmyślnego polecenia. Piszą oni na przykład: „zamierzony i zależny od celu automatyzm jest oczywistym wynikiem wykonywania wysoce wyspecjalizowanych czynności (...). Dobrze przyswojone skrypty sytuacyjne lub wysoce zrutynizowane sekwencje działań mają zazwyczaj charakter autonomiczny i nie wymagają dużej ilości świadomej kontroli lub specjalnych zasobów uwagi. Zachowania wymagające umiejętności podpadają pod kategorię automatyzmu, podobnie jak znajomość określonych procedur, która w wyniku częstego stosowania stała się niezależna od świadomej kontroli (jak na przykład prowadzenie samochodu)"79. Zgadza się to $z$ nakreślonymi przez Slingerlanda wczesnokonfucjańskimi koncepcjami nabywania cnót na drodze rytuałów oraz ze spostrzeżeniem Annas, że w miarę nabywania doświadczenia wykonywanie wyspecjalizowanych czynności zaczyna przebiegać niezależnie od świadomego namysłu nad motywami działania.

77 Tamże, s. 29-30.

78 D. Narvaez, D.K. Lapsley, The Psychological Foundations of Everyday Morality and Moral Expertise [w:] D.K. Lapsley, C. Power (eds.), Character Psychology and Character Education, Notre Dame 2005, s. I40-I65.

79 Tamże, s. I45. Skrypty to opisy sekwencji działań, używane przez nas do kierowania naszym zachowaniem w różnych sytuacjach. Na przykład skrypt „bufet” opisuje sekwencję działań związanych z otrzymaniem posiłku - ustawienie się w kolejce, uiszczenie zapłaty i zajęcie miejsca. Z kolei skrypt „restauracja” może zawierać poczekanie na wskazanie stolika, wybór dania $z$ karty, obsługę przez kelnera i przyjęcie rachunku. Skrypty mogą być ważne w nauce cnotliwego postępowania. Poprzez skrypty dzieci mogą się na przykład uczyć, jak być szczodrymi i dzielić się z innymi oraz jak i kiedy należy pomagać innym. 
Postświadomy automatyzm, „działający po ostatnim świadomym doświadczeniu lub ostatnim wykorzystaniu zasobów uwagi" ${ }^{80}$, również pełni rolę w procesie uczenia się cnoty. Chodzi o to, że skoro tylko konstrukty cnoty zostają „wbudowane” w czyjś umysł, stają się dostępne dla celów przetwarzania informacji, i to w sposób nieświadomy, albo stale, albo dzięki sytuacyjnej aktywizacji wstępneje ${ }^{81}$. Sytuacjoniści przywołują pojęcie sytuacyjnej aktywizacji wstępnej (na przykład wolne podchodzenie do windy po przeczytaniu określonych słów w zaszyfrowanym zdaniu), by zilustrować, że jesteśmy mniej świadomi oddziałujących na nas czynników i mamy mniej świadomej kontroli nad swoim zachowaniem, niż myślimy. Zgodnie $z$ podanym przez Slingerlanda opisem wykorzystywania sytuacji i jego analizą tekstów konfucjańskich dotyczących moralnego rozwoju Narvaez i Lapsley omawiają stałą aktywizację wstępną jako narzędzie umożliwiające nam nauczanie i uczenie się cnoty. Gdy uczymy cnoty nasze dzieci, wielokrotnie przedstawiamy im pojęcia cnoty oraz ich znaczenie i zastosowanie w różnych sytuacjach społecznych w nadziei, że zinternalizują one skrypty, które pokażą im, jak być cnotliwymi ludźmi. Jak zwracają uwagę sytuacjoniści, sytuacyjna aktywizacja wstępna jest jednym $z$ krótkotrwałych przejawów postświadomej automatyczności. Bardziej interesujący jest pomysł, że uczenie się przez dzieci cnoty na drodze wielokrotnego napotykania skryptów może zaowocować trwałymi lub utrzymującymi się przez jakiś czas przejawami cnoty, przez co dzieci, przyswajając wskazówki co do tego, jak postępować cnotliwie, z czasem zaczną tak postępować, rozwijając ostatecznie cnotliwe dyspozycje jako część kształtującego się charakteru.

Narvaez i Lapsley piszą: „większość z tego, co wiemy i czego się uczymy, jest utajona"82. Proponują oni teorię nauki moralności jako nabywania doświadczenia nadbudowującego się na utajonej wiedzy, w czym zgadzają się zarówno ze Slingerlandem, jak i z Annas. Doświadczenie w cnocie nie jest wyłącznie kwestią jej rozwoju

\footnotetext{
80 D. Narvaez, D.K. Lapsley, The Psychological Foundations..., dz. cyt., s. I44.

81 Tamże, s. I46-I47.

82 Tamże, s. I48.
} 
$\mathrm{w}$ kontekście automatycznego zmierzania do celu lub stosowania się do zinternalizowanych skryptów, lecz wymaga namysłu i umiejętności wyjaśnienia swoich działań w kategoriach rozumowych. Kluczem do rozwoju doświadczenia jest praktyczna racjonalność. Poprzez świadome rozumowanie integrujemy naszą wiedzę i rozwijamy umiejętności gromadzone nieświadomie. Nieświadome procesy nie tylko nie zakłócają naszych wysiłków na drodze do cnoty, lecz mogą także zostać wykorzystane do jej rozwoju pod przewodnictwem praktycznego rozumu. Teoria Narvaez i Lapsleya ${ }^{83}$ była stosowana w szkołach publicznych w Minnesocie, dowo$\mathrm{d} z a ̨ c, \dot{z}$ e rozwój cnoty żyje i ma się dobrze w świecie empirycznym.

\section{Wniosek}

W tej pracy próbowałam przedstawić dwie linie sytuacjonistycznej krytyki etyki cnót i odpowiedzieć na nie. Uważam, że obie chybiają celu i etyka cnoty stanowi obiecujące i wykonalne podejście do etycznej teorii i praktyki. W moim przekonaniu jesteśmy winni sytuacjonistom wdzięczność za impuls do zwrócenia się w kierunku psychologii empirycznej w poszukiwaniu dowodów na rzecz etyki cnoty. Empiryczna psychologia nie tylko nie podkopuje etyki cnoty, lecz w pełni obrazuje także jej przystawalność do ludzkich procesów psychologicznych i możliwości dalszego rozwoju.

Przetożyt Patryk Krajewski

\section{Bibliografia}

Anderson C., Deuser W., DeNeve K., Hot Temperatures, Hostile Affect, Hostile Cognition, and Arousal: Tests of a General Model of Affective Aggressiveness, „Personality and Social Psychology Bulletin” 2I (1995), s. 434-448.

Tamże, s. I60-I6I, przyp. 4. 
Annas J., Intelligent Virtue, New York: Oxford University Press, 201 I. Bargh J.A., Conditional Automaticity: Varieties of Automatic Influence in Social Perception and Cognition [w:] J.S. Uleman, J.A. Bargh (eds.), Unintended Thoughts, New York: Guilford, I989, s. 3-5I.

Bargh J.A., Auto-Motives Preconscious Determinants of Social Interaction, [w:] E.T. Higgins, R.M. Sorrentino (eds.), Handbook of Motivation and Cognition: Foundations of Social Behavior, New York: Guilford, I990, s. 93-I30.

Bargh J.A. (ed.), Social Psychology and the Unconscious: The Automaticity of Higher Mental Processes, New York: Psychology Press, 2007. Bargh J.A., Ferguson M., Beyond Behaviorism: On the Automaticity of Higher Mental Processes, „Psychological Bulletin” I26 (2000), s. $925-945$.

Bargh J.A., Gollwitzer P.M., Environmental Control of Goal-Directed Action: Automatic and Strategic Contingencies Between Situation and Behavior [w:] W.D. Spaulding (ed.), Integrative Views of Motivation, Cognition, and Emotion, Lincoln: University of Nebraska Press, I994, S. 7I-I24.

Bargh J.A. i in., The Automated Will: Nonconscious Activation and Pursuit of Behavioral Goals, "Journal of Personality and Social Psychology" 8I (200I), s. I0I4-IO27.

Baron R., The Sweet Smell of... Helping: Effects of Pleasant Ambient Fragrance on Prosocial Behavior in Shopping Malls, „Personality and Social Psychology Bulletin" 23 (1997), s. 498-503.

Batson C.D. i in., Failure to Help When in a Hurry: Callousness or Conflict?, „Personality and Social Psychology Bulletin” 4 (I978), s. 97-IoI. Chartrand T.L., Bargh J.A., Automatic Activation of Impression Formation and Memorization Goals: Nonconscious Goal Priming Reproduces Effects of Explicit Task Instructions, "Journal of Personality and Social Psychology" 7I (I996), s. 464-478.

Darley J.M., Batson D., From Jerusalem to Jericho: A Study of Situational and Dispositional Variables in Helping Behavior, "Journal of Personality and Social Psychology" 27 (I973), s. I00-108.

Devine P.G., Stereotypes and Prejudice: Their Automatic and Controlled Components, ,Journal of Personality and Social Psychology" 56 (I989), s. 5-I8.

Devine P.G., Monteith M.J., Automaticity and Control in Stereotyping [w:] S. Chaiken, Y. Trope (eds.), Dual-Process Theories in Social Psychology, New York: Guilford, 1999, s. 339-360. 
Devine P.G., Plant A., Buswell B.M., Breaking the Prejudice Habit: Progress and Obstacles [w:] S. Oskamp (ed.), Reducing Prejudice and Discrimination, Mahwah, NJ: Erlbaum, 2000, s. I85-210.

Doris J.M., Persons, Situations, and Virtue Ethics, „Nous” 32 (I998), s. 504-530.

Doris J.M., Lack of Character: Personality and Moral Behavior, Cambridge, UK: Cambridge University Press, 2002.

Doris J.M., Précis of Lack of Character, „Philosophy and Phenomenological Research" 7I (2005), s. 632-634.

Doris J.M., Skepticism About Persons, „Philosophical Issues” 19 (2009), s. 57-9I.

Doris J.M., E-mail message to author, 2 January 2012.

Doris J.M., STich S.P., As a Matter of Fact: Empirical Perspectives on Ethics [w:] F. Jackson, M. Smith (eds.), The Oxford Handbook of Contemporary Philosophy, New York: Oxford University Press, 2005, S. II4-I52.

Gray J.A., McNaughton N., The Neuropsychology of Anxiety: An Enquiry into the Functions of the Septo-Hippocampal System, New York: Oxford University Press, 2000.

Harman G., Moral Philosophy Meets Social Psychology: Virtue Ethics and the Fundamental Attribution Error, „Proceedings of the Aristotelian Society" 99 (I999), s. 3I5-33I.

Harman G., The Nonexistence of Character Traits, „Proceedings of the Aristotelian Society" I00 (2000), s. 223-226.

Hartshorne H., May M.A., Studies in the Nature of Character, Vol. I: Studies in Deceit, New York: Macmillan, I928.

Hassin R.R., Uleman J.S., Bargh J.A., The New Unconscious, New York: Oxford University Press, 2005.

Hursthouse R., On Virtue Ethics, Oxford: Oxford University Press, I999.

Isen A.M., Levin P.F., Effect of Feeling Good on Helping: Cookies and Kindness, ,Journal of Personality and Social Psychology" 2I (I972), s. 384-388.

Kamtekar R., Situationism and Virtue Ethics on the Content of Our Character, „Ethics” II4 (2004), s. 458-49I.

Lapsley D.K., Hill P.L., On Dual-Processing and Heuristic Approaches to Moral Cognition, "Journal of Moral Education” 37 (2008), s. 3I3-332.

Latané B., Darley J.M., The Unresponsive Bystander: Why Doesn't He Help?, Englewood Cliffs, NJ: Prentice-Hall, I970. 
McCrae R.R., Costa P.T. Jr., Toward a New Generation of Personality Theories: Theoretical Contexts for the Five-Factor Model [w:] J.S. Wiggins (ed.), The Five-Factor Model of Personality: Theoretical Perspectives, New York: Guildford Press, I996, s. 5I-87.

McDowell J., Virtue and Reason, „Monist” 62 (I979), s. 33I-350.

McDowell J., Two Sorts of Naturalism [w:] R. Hursthouse, G. Lawrence, W. Quinn (eds.), Virtues and Reasons: Philippa Foot and Moral Theory, Oxford: Clarendon Press, 1995, s. I49-I79.

Merritt M.W., Virtue Ethics and Situationist Personality Psychology, „Ethical Theory and Moral Practice” 3 (2000), s. 365-383.

Merritt M.W., Aristotelian Virtue and the Interpersonal Aspect of Ethical Character, "Journal of Moral Philosophy" 6 (2009), s. 2-49. Merritt M.W., Doris J.M., Harman G., Character [w:] J.M. Doris and the Moral Psychology Research Group (eds.), The Moral Psychology Handbook, Oxford: Oxford University Press, 2010, s. 355-40I.

Milgram S., The Individual in a Social World: Essays and Experiments, Reading, MA: Addison-Wesley, I977.

Mischel W., Personality and Assessment, New York: Wiley, 1968.

Mischel W., Shoda Y., A Cognitive-Affective System Theory of Personality: Reconceptualizing Situations, Dispositions, Dynamics, and Invariance in Personality Structure, „Psychological Review” I02 (I995), s. 246-268. Monteitr M.J., Self-Regulation of Prejudiced Responses: Implications for Progress in Prejudice Reduction Efforts, "Journal of Personality and Social Psychology" 65 (1993), s. 469-485.

Mower D.S., Situationism and Confucian Virtue Ethics, „Ethical Theory and Moral Practice" I6 (2013), s. II3-I37.

Narvaez D., Lapsley D.K., The Psychological Foundations of Everyday Morality and Moral Expertise [w:] D.K. Lapsley, C. Power (eds.), Character Psychology and Character Education, Notre Dame, IN: University of Notre Dame Press, 2005, s. I40-165.

Newсомв T.M., The Consistency of Certain Extrovert-Introvert Behavior Patterns in 51 Problem Boys, New York: Columbia University, Teachers College, Bureau of Publications, I929.

Russell D.C., Practical Intelligence and the Virtues, Oxford: Oxford University Press, 2009.

Sabini J., Silver M., Lack of Character? Situationism Critiqued, „Ethics” II5 (2005), s. 535-562.

Slingerland E., The Situationist Critique and Early Confucian Virtue Ethics, „Ethics” I2I (201I), s. 390-4I9. 
Snow N., Virtue as Social Intelligence: An Empirically Grounded Theory, New York: Routledge, 20Io.

Snow N., Situationism and Character: New Directions [w:] S. van Hooft (ed.), Handbook of Virtue Ethics, London \& New York: Routlege 2014. Swanton C., Virtue Ethics: A Pluralistic View, Oxford: Oxford University Press, 2003.

Zagzebsei L.T., Virtues of the Mind: An Inquiry into the Nature of Virtue and the Ethical Foundations of Knowledge, New York: Cambridge University Press, 1996.

\section{Key words Abstract}

virtue ethics, In light of the situationist critique of virtue ethics, is there situationism, character or virtue? I believe there is, in the philosophicalAristotelia- ly traditional sense of 'character' and 'virtue' defended by nism, Aristotle. To make good this claim, I proceed in several character stages. In part I, I sketch what I take to be the standard Aristotelian picture of virtues and their relation to actions. This picture is the target of the situationist critique. In part 2, I outline situationist objections to global traits, and in 3 offer possible lines of response. Parts 2 and 3 draw extensively on my book, Virtue as Social Intelligence: An Empirically Grounded Theory. In parts 4 and 5, I address recent situationist attacks on the cognitive integration of personality. There I explore several lines of response in the philosophical and psychological literature on virtue.

Nancy E. Snow jest profesorem filozofii na Uniwersytecie Marquette w Milwaukee, stan Wisconsin, USA. Zajmuje się etyką cnót i psychologią moralną. Jej najważniejsze publikacje to monografia Virtue as Social Intelligence: An Empirically Grounded Theory (Routledge, 2010), The Philosophy and Psychology of Character and Happiness, współredagowana $z$ Frankiem V. Trivigno (Routledge, 20I4), oraz redagowany przez nią tom Cultivating Virtue: Perspectives from Philosophy, Theology, and Psychology (Oxford, 20I4).Adres e-mail: nsnow@ou.edu. 